\title{
Sustainable Adaptation Strategies for Water Resource Protection: A Case Study of Nanxi River in China
}

\author{
Jianming Guo ${ }^{1}$, Jie Liu ${ }^{1}$, Shibao Lu ${ }^{1, *}$ and Farhad Taghizadeh-Hesary ${ }^{2, *}$ (i) \\ 1 School of Public Administration, Zhejiang University of Finance and Economics, Hangzhou 310018, China; \\ jmguo@zufe.edu.cn (J.G.); liujielj@zju.edu.cn (J.L.) \\ 2 Social Science Research Institute, Tokai University, Hiratsuka-shi 259-1292, Kanagawa-ken, Japan \\ * Correspondence: lu5111284@aliyun.com (S.L.); farhad@tsc.u-tokai.ac.jp (F.T.-H.)
}

Received: 10 July 2020; Accepted: 25 August 2020; Published: 28 August 2020

\begin{abstract}
Collective action is a basic premise for the effective protection of open public resources. The characteristics and the environment of open public resources, however, also constitute many "bottlenecks" to collective action, which means that there is a "paradoxical" relationship between collective action and open public resources. Therefore, the key to protecting open public resources is to construct a collective action mechanism that can break these "bottlenecks". In the case of three different forms of contract system implemented by Yongiia County, Zhejiang Province, China for the fishery resources of Nanxi River, the first two contracts were caught up in the "tragedy of the commons" and a legality crisis because they did not form a collective action mechanism to protect resources. The sub-contract with the aim of protecting and resting the Nanxi River started in 2005 and has constructed a collective action mechanism of consensus, sharing, common participation, joint discussion and co-management, and worked out a rationale of how to form collective action in the process of open public resource protection, which is worth exploring and promoting. This study aims to explore the bottlenecks which limit collective action in the process of resource protection, and to provide practical policy recommendation for solving them.
\end{abstract}

Keywords: public resources; water right contract; collective action mechanism; resource protection; economic strategies; sustainable strategies

\section{Introduction}

In the model selection for public resource management, there has always been a confrontation between the "Leviathan" model and the privatization model. The "Leviathan" model is prone to result in invalidation while the privatization model has been questioned about its legitimacy. After the rise of the New Public Management Movement, the public-private contract model became popular. Since 1984, Yongjia County in Zhejiang province of China started to implement three different forms of contract, but each form has different results. The key point is whether an effective collective action mechanism can be established to protect resources.

Collective Action Theory in the management sense originated from Mayo's Factory Human Relationship Theory and Lewin's Group Dynamics Theory in the 1920s and 1930s. Although both of these studies of the group selection problem in industrial management, with the aim of dealing with personal interests according to the needs of their times, do not deal with the identical problems of choice facing the collective interest in public management, the truth revealed by them is the same [1]. Mayo's Factory Human Relationship Theory tells us that, even if individuals pursue their own interests under formal institutional arrangements, they are not fully free but will be constrained by stakeholder groups and need to recognize these [2]. Despite such constraint and that this recognition is informal, it is very effective. Lewin's Group Dynamics Theory interprets individual behavior as a function 
of interaction between the individual and the environment, i.e., $\mathrm{B}=f(\mathrm{P} \cdot \mathrm{E})$ and he applies this functional relationship to the study of group behavior on the condition that factors such as group regulation, communication, and organizational leadership are added [3,4]. Collective Action Theory in public management began to grow in the next two decades. Until the 1980s and 1990s, it experienced roughly three stages of development: the idealistic stage, the empirical stage and the institutionalist stage. The idealistic stage is the one represented by Bentley (1908) and Truman (1952). They published a book with almost the same title, Management Process, arguing that persons with common interests will voluntarily act to promote these common interests and regard common interests as a necessary and sufficient condition for collective action. So, they are optimistic about collective action. The empirical stage is represented by Olson (1965) and Hardin (1968). They are relatively pessimistic about collective action. In his book The Logic of Collective Action, Olson challenges the idealistic collective action concept from the perspective of normal characteristics of human rationality and self-interested behavior in economic activities. He said: "Unless there is a relatively small number of people in a group, or there is a coercive or other means to motivate individuals to act for their common interests, otherwise rational individuals seeking their own interests will not take actions for their common interests or group interests". This assertion has three meanings: firstly, the common interest is only a necessary condition for inspiring collective action, not a sufficient condition; secondly, there is a possibility to produce collective action around common interests in small, simple groups; thirdly, coercion is an indispensable means of maintaining large-scale collective action $[5,6]$. Harding's metaphor of the "tragedy of the commons" further reveals a paradox: that it is impossible to achieve optimized collective action if there are no effective measures to regulate the individual's preference for a "free rider" [7,8]. The institutionalist stage is represented [9] who took an initiative attitude towards collective action. For example, it is necessary to establish a fisheries management agency with a wider range of stakeholders, which is conducive to arousing public attention to fisheries management and embodying multiple interests in decision-making. Knut and Svein (2001) applied stakeholder theory to fisheries management. They pointed out that how to identify and manage multiple stakeholders at the same time is the key to the problem. Stakeholder integration has a moderating effect on the implementation of environmental protection strategy [10], and ecosystem-based considerations are needed in fisheries management more than just the needs of stakeholders and fisheries [11].

In Ostrom's book entitled The Governance of Public Affairs-The Evolution of Collective Action Systems, he focuses in the possibility of collective participants changing their game environment autonomously, and thinks that the mistake of the traditional "dilemma" theory is to regard the collective members as the recipients of environmental pollution. In fact, in systems other than the totalitarian system, the ability of interdependent group members to independently change the game environment and evade "free-riding" and other opportunistic behaviors is enormous. The question is how to cultivate this potential system. To this end, Ostrom proposed eight principles of designing a collective action mechanism for sustainable public resource management based on the operational rule, the rule of collective choice and constitutional rule: clearly defining resource boundaries; occupation and supply rules adapted to the local situation; equality of collective rights; supervising all parties involved in resource management and occupation; grading of sanctions; low-cost and convenient conflict resolution mechanism; the right to retain the independent design of local systems; and a management system of power separation [12]. According to his observation, an effective collective action mechanism for public resource management may not fully satisfy the conditions above, but there is still a positive correlation between the effectiveness of management and the extent to which the conditions above are met. Although the collective action system designed by Ostrom is only applied to a small-scale public resource, its logic is also a good guide to the design of a collective action mechanism for large-scale and open public resource management $[13,14]$

Large-scale and open public resources can constitute a more complex system. According to Wantrapo and Bishop, so-called open public resources are resources with unclear ownership of property rights, which is contrary to resources whose property right belongs to groups according to strict 
stipulation $[15,16]$. These kinds of resources are also called closed public resources, such as village pasture, meadows, woodland, irrigation canals, etc. The state-owned public resources, such as water systems, forest farms, and large offshore fisheries, are often a mixture of open and closed public resources. However, due to subjective and objective limitations, state-owned property rights of these resources are often difficult to achieve effectively, and thus their openness characteristics are more obvious $[17,18]$. Based on the analyses above, the paper classifies this kind of resource as a state-owned open public resource. Compared with a closed public resource, an open public resource has many factors which make it difficult to stimulate protection actions from groups, in addition to property rights not being clear or easy to achieve $[19,20]$. Firstly, the occupants of open public resources are often not specific. The behavior of occupying these resources is not limited by time of occupation nor amount of resources [21]. Some are only occasionally occupied, and there is no regularity [22,23], with activities such as cutting trees, stealing fish, etc., which will greatly increase institutional cost, supervisory cost and exclusive cost of management. Secondly, resource occupants usually act independently or are relatively unfamiliar with each other, and it is not easy to reach a consensus on collective action. Thirdly, under open conditions, there is a lack of relationship between resource occupants and resources, which results in the high discount rate of occupied resources. Therefore, open public resources are prone to fall into the "tragedy of the commons" [24,25]. Closed public resources are generally distributed in more conventional society. Even if the initial distribution is not standardized, and may fall into the "tragedy of the commons", it is much more likely to achieve common interests through contact, for production and the life of the members are deeply affected by the stock and quality of the resources and the resource occupants have deeper feelings about these resources [26]. It is more convenient for members to supervise and exchange information, and they are much more likely to achieve common interests through contract. Comparing the characteristics of two types of public resource, we can find that there are five "bottlenecks" which limit collective action in the process of resource protection: low recognition of the collective action; the conflict of interest with stakeholders; the high exclusive cost of resource protection; the high resource discount rate of occupants; and the difficulty in supervision $[27,28]$. Collective action, however, is necessary if the open public resources need to be effectively protected.

\section{Case Description and Theoretical Presupposition}

\subsection{Case Description}

Located in Yongjia County, Zhejiang Province, Nanxi River is $26 \mathrm{~km}$ away from Wenzhou City, adjacent to Yandang Mountain in the East (Figure 1).The total length of the main stream is $140 \mathrm{~km}$, the drainage area is about 2490 square kilometers, the natural fall of the river course is $1030 \mathrm{~m}$, the average slope is $7.4 \%$, the average width of the upper and middle reaches is $50 \mathrm{~m}$, the average width of the lower reaches is $375 \mathrm{~m}$, and the average annual runoff is 2.85 billion cubic meters. It is a water system with high-quality resources such as rare fisheries, clean water and rural tourism [29].

In terms of the development and protection of this water system, it has experienced three contract models: the sub-contracting of zero-sum; the overall contract of comprehensive confrontation; and the composite contracting of management and protection. This vividly interprets the growth process of the collective action mechanism for open public resource protection and development.

Before 1984, the fishery resource in Nanxi River was at a free fishing stage without any protection. With the successful promotion of the land contract model and the recognition of the economic value of the fishery resource in Nanxi River, Yongjia County hopes to use the contract model to turn the fishery resource into money, which means earning a compensation fee for resource protection. Hence in the same year, the fishery resource in the Nanxi River was contracted. The county government designated about half of the waters of Nanxi River as within the contract's scope, allowing units, organizations, and natural persons to participate in contracting as collectives, partners, and individuals. All contractors pay a resource occupation fee according to the area of the water to obtain fishing rights 
in the contracted waters. As a result, the fishery resource in Nanxi River has become a typical "tragedy of the commons". The amount of fish produced is less and less, and the resource fees paid by the contractors are also less. The expected economic and social benefits at the beginning of the contract were lost.

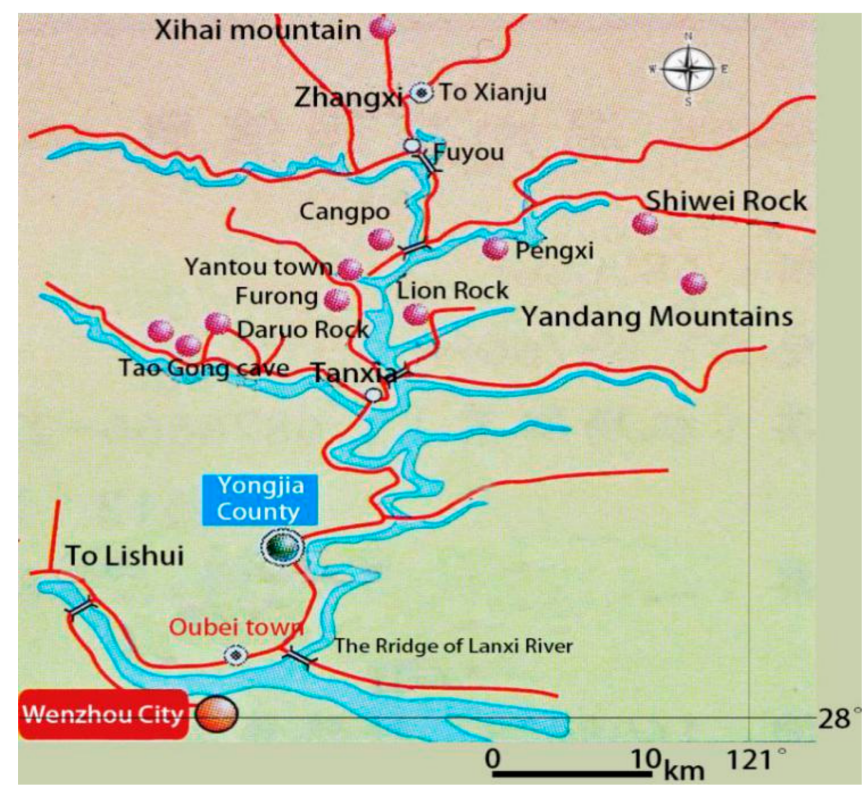

Figure 1. Nanxi River, Zhejiang Province.

In response to the destruction of the fishery resources and the environment by the subcontract, the Agriculture Bureau of Yongjia County decided to terminate the previous contract, and in 1998 the whole watershed covering $145 \mathrm{~km}$ of the basin water management was bid to society by means of overall contract. However, this time, contracting of the Nanxi River did not follow the logic of "from total contracting to unified management to economies of scale to sustainable development of fishery resources protection" as presupposed by the contract party and the party who offered the contract. Instead, the result is: from contract to comprehensive confrontation, then to the end of the dispute, and finally to the deterioration of the fishery resources.

In view of the fact that the overall contract was criticized and difficult to fulfill, in 2005 Yongjia County implemented a "composite contract" of operation, management and protection of the fishery resources in Nanxi River through cooperation between the county, town and village. Compared with the previous two simple contracts, the biggest difference of this "composite contract" is its compatibility. The main characteristic are as follows: the purpose of the contract is to protect the river and take care of the river, which means to protect and manage resource, thus government's obligation is combined with effective measures from the riverside villagers in raising the river; as for contract management, it combines closed fishing, fishing ban and segment management, which means that the contractor does not obtain fishing rights for the whole period of time, but must obey the regulations of closed fishing and fishing ban imposed by the contractor, which is conducive to avoiding fishery resources falling into the "tragedy of the commons". From 2005 to 2018, after the implementation of the new combination model of protecting fish, resting the river and protecting the environment, the regulation, protection and management of the fishery resources in Nanxi River have been comprehensively improved. So, the protection and cultivation of the fishery, high-quality water and tourism in Nanxi River has entered a benign cycle. The differences between these three contract systems are shown in Table 1. 
Table 1. Differences between the fishery contracts.

\begin{tabular}{|c|c|c|c|c|}
\hline $\begin{array}{l}\text { Contracting } \\
\text { Methods }\end{array}$ & Contractor & Contract Management & Contractual Benefits & Impact and Results \\
\hline $\begin{array}{l}\text { Sub-contracting of } \\
\text { zero-sum } \\
(1984-1998)\end{array}$ & $\begin{array}{c}\text { County Fishery } \\
\text { Administration } \\
\text { Bureau, Coastal } \\
\text { Villagers } \\
\text { Committee and } \\
\text { Villagers }\end{array}$ & $\begin{array}{l}\text { The contractor shall pay } \\
\text { the resource occupancy } \\
\text { fee separately }\end{array}$ & $\begin{array}{l}\text { The county fishery } \\
\text { administration } \\
\text { department collects the } \\
\text { resource occupancy fee }\end{array}$ & $\begin{array}{l}\text { The amount of fish } \\
\text { produced is less and } \\
\text { less, and the resource } \\
\text { fees paid by the } \\
\text { contractors are also } \\
\text { less. "Tragedy of } \\
\text { the commons". }\end{array}$ \\
\hline $\begin{array}{l}\text { The overall } \\
\text { contract of } \\
\text { comprehensive } \\
\text { confrontation } \\
(1998-2004)\end{array}$ & $\begin{array}{l}\text { Monopolistic } \\
\text { contracting by } \\
\text { four partners }\end{array}$ & $\begin{array}{c}\text { In the form of social } \\
\text { bidding, the winning } \\
\text { bidder shall contract as a } \\
\text { whole }\end{array}$ & $\begin{array}{l}\text { The contract fee is } \\
\text { collected by the county } \\
\text { agriculture bureau, } \\
\text { the villagers along the } \\
\text { river are deprived of } \\
\text { their original fishing } \\
\text { interests, their living } \\
\text { becomes inconvenient, } \\
\text { and the original contract } \\
\text { income of the county } \\
\text { fishery administration } \\
\text { department is deprived }\end{array}$ & $\begin{array}{l}\text { The villagers along the } \\
\text { river use a variety of } \\
\text { ways to steal fish; } \\
\text { poisonous fish, fried } \\
\text { fish and free fishing, } \\
\text { resulting in the } \\
\text { contractor's economic } \\
\text { interests damaged; } \\
\text { ecological damage } \\
\text { failed to improve. }\end{array}$ \\
\hline $\begin{array}{l}\text { The composite } \\
\text { contracting of } \\
\text { management and } \\
\text { protection (2004-) }\end{array}$ & $\begin{array}{l}\text { Township (town) } \\
\text { governments, } \\
\text { village } \\
\text { organizations and } \\
\text { villagers along } \\
\text { the river }\end{array}$ & $\begin{array}{l}\text { Government's obligation } \\
\text { is combined with } \\
\text { effective measures of } \\
\text { riverside villagers } \\
\text { raising the river; as for } \\
\text { contract management, } \\
\text { it combines closed } \\
\text { fishing, fishing ban and } \\
\text { segment management. }\end{array}$ & $\begin{array}{l}\text { Governments, villagers, } \\
\text { and ecosystems benefit, }\end{array}$ & $\begin{array}{l}\text { There is no large-scale } \\
\text { fishing. The protection } \\
\text { and cultivation of the } \\
\text { fishery, high-quality } \\
\text { water and tourism in } \\
\text { Nanxi River has } \\
\text { entered a benign cycle. }\end{array}$ \\
\hline
\end{tabular}

\subsection{Incentive and Compatible Mechanism of Collective Action}

From what theoretical perspective should we interpret how these three contract systems have different conclusions? Based on the analyses of the legitimacy of interests, powers and responsibilities and subject negotiation, it can be found that the protection of open public resources requires the construction of a compatible mechanism of collective action.

Incentive compatibility refers to an arrangement that enables the pursuit of personal interests to coincide with the goal of maximizing collective value [30]. If expressed by Kurt Lewin's Group Dynamics Theory's model $\mathrm{B}=f(\mathrm{P} \cdot \mathrm{E}), \mathrm{P}$ is the number of interdependent resource occupants or contractors, and $\mathrm{E}$ represents the various components of the collective action mechanism. If each part of a collective action mechanism is relatively sound and fully functional, it can stimulate the resource occupants or contractors and resource stakeholders, and the possibility of collective action to protect resources is greater or vice versa. An effective collective action mechanism should have at least a subsystem to solve these problems: the incentive-compatible mechanism of recognition. This seeks to form a collective action consensus for protecting the common resource system among the parties that do not recognize ownership but share the resources.It based on unspoken rules that the ownership of the jurisprudence and the ownership of the private self-identification were recognized.

(1) This includes establishing the interaction mechanism and communication mechanism for the resource occupants, and striving to transform the independent, decentralized and unfamiliar resources parties into "the familiar society" to enhance mutual trust.

(2) The incentive-compatible mechanism of benefit. This mechanism seeks shared benefits based on resource protection between both parties who conflict regarding ownership, the state-owned property rights party and the resource-owned areas. Benefit sharing is the legal basis for collective action. In the protection and operation of state-owned open public resources, it is necessary to fully take the interests of the parties in the resource territories into consideration, which means not only avoiding 
the compulsory method of the state-owned enterprise making all profits or running by monopoly, but also preventing rational, dominant or decentralized opportunistic behavior of the free-riding and the pursuing of self-interest.

(3) Incentive compatibility mechanism of behavior. This seeks a combination of collective actions for protecting resources from the bottom to the top and from the top to the bottom. The focus is to cultivate relationships between resource occupants and resource systems, realizing the integration of the behaviors of resource occupants within a specific scope and enabling collective action to freely protect resources from the bottom to the top. At the same time, establishing an exchange mechanism and mutual cooperation mechanism for resource information for the resource users promotes mutual trust, interdependence and mutual supervision among the users of adjacent resources, and imposes sanctions on those who use resources maliciously, to form a comprehensive collective action for protecting open public resources.

(4) The incentive compatibility mechanism of power and responsibility. This seeks that all parties involved in public resources enjoy the right to participate, to gain knowledge and to vote in accordance with their own identity in the process of formulating and modifying the rules for the disposal of public resources. On the one hand, this can make the rules more relevant to the local situation in order to improve the effectiveness of these rules; on the other hand, it is also an important way to ensure the sustainability of collective action. So it is necessary to establish rules to determine the negotiation mechanism, the information feedback mechanism of rule execution, and the formulation mechanism of the new rules, in the nature of a public forum, and to include resource management parties, local organizations, resource protection contractors and other resource stakeholders in the community of institutional arrangements.

(5) The incentive compatibility mechanism of regulation. This seeks cooperation between various functional departments of public resource management and unified management of each resource occupant.

The five sub-mechanisms mentioned above guarantee the legitimacy, usefulness, effectiveness, continuity, and unity of collective action. respectively, and build a collective action mechanism compatible with identity, interests, behaviors, powers and responsibilities, and regulatory incentives (Figure 2).

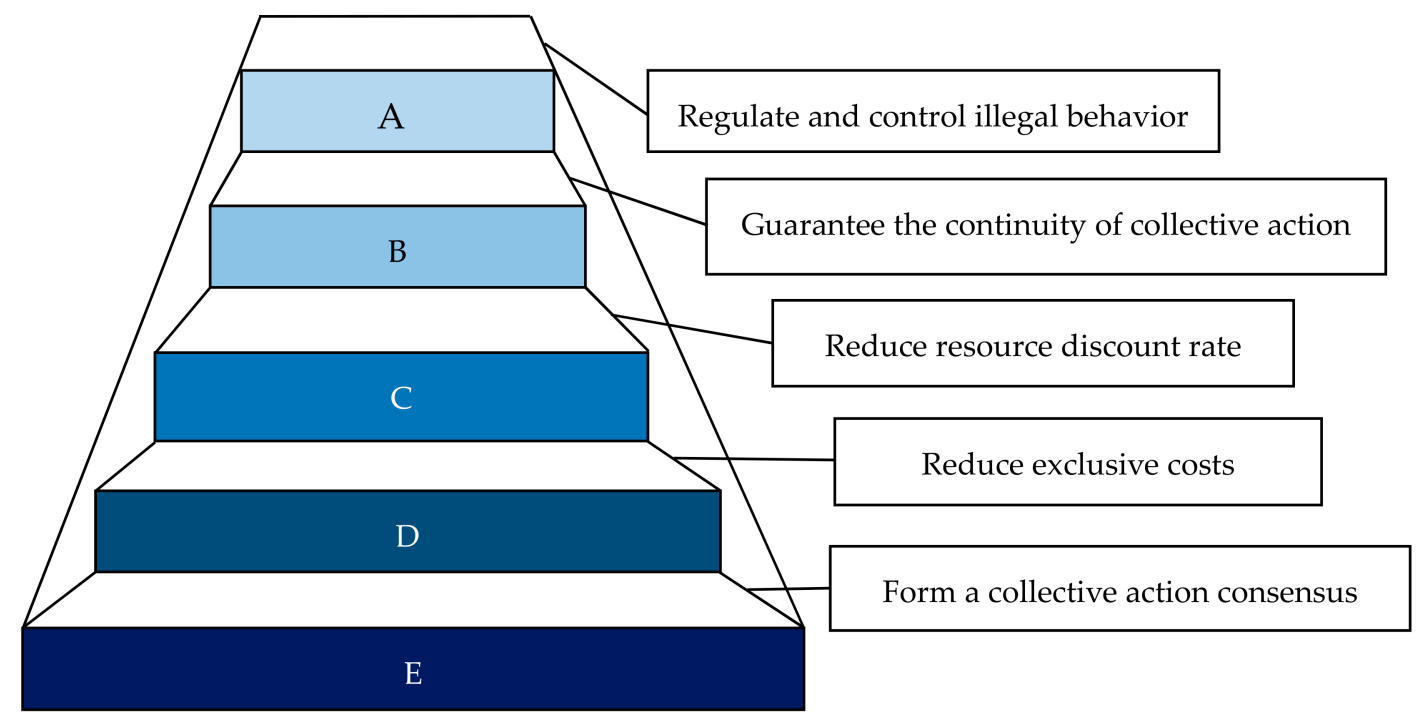

Figure 2. Incentive-compatible Collective Action Mechanism and Its Functions. A. The incentive compatibility mechanism of regulation; B. The incentive compatibility mechanism of power and responsibility; $\mathbf{C}$. The incentive compatibility mechanism of behavior; $\mathbf{D}$. The incentive compatibility mechanism of interest; E. The incentive compatibility mechanism of recognition. Source: Authors' depiction. 


\section{The Application Results of the Incentive and Compatible Collective Action Mechanism}

\subsection{Establish a Resource View of Development and Conservation and Form a Collective Action Consensus}

During the previous two contracts, the Yongjia County government, the contractor, and the villagers along the Yangtze River held three flawed views of the fishery resources in the Nanxi River. The first is a single resource concept, as fishery resources in the Nanxi River were separated from the high-quality water resources and tourism resources when considering planning. The second is to focus on management and ignore protection, and to unilaterally pursue the economic benefits of contracting the fishery resources, so that awareness of protecting the river is weak. The third, the stubborn view of state-owned resources (i.e., those living on a mountain live off the mountain, those living near the water live off the water, just to make a living in one's given circumstances) held by the resource authorities, confronts the free resource view of villagers along the Yangtze River, resulting in a "fishing competition" and "legality crisis" in terms of the contract. After all the parties involved in the relevant fishery resources in the Nanxi River had undergone contracting and restructuring for nearly 20 years, the county fishery administration proposed "protecting resources in the Nanxi River", advocating and guiding all parties to consider the neglected resources point of view. On the one hand, the county fishery authorities and the government in Nanxi town carry out a publicity month regarding fishery regulations every year, so as to improve the people's awareness of the law and to strengthen their love of the river. On the other hand, the government and the people should jointly participate in public discussion about the conservation of resources in the Nanxi River and guide the villagers along the Yangtze River to understand the concept of healthy, civilized resources. During the public discussion, ideas that reflected the overall concept of resources, the combination of nursing and caring, and the idea of protecting the river by all people were widely recognized. This consensus led to a psychological accumulation of thinking about the new contract system and supporting the collective protection of the river. In particular, it has broken the misunderstanding of "the supremacy of economic interests" and established the consensus that "no matter what kind of contracting method is adopted, protecting the river and raising the river should be the core of policy attention", vividly reproducing the logical progression from establishing a new view of resources, to forming a consensus on protecting the river, to collective action for resource protection.

\subsection{Enjoy the Benefits and Interests Produced by State-Owned Resources and Reduce the Exclusive Cost}

However, sustainable collective action cannot be achieved just by recognition. It is necessary to have a stable interest distribution mechanism to allow all parties involved to achieve benefits from the collective action of protecting resources. During the extensive subcontracting period from 1984 to 1998, it seemed that the villagers along the Yangtze River received contracted income, and the government authorities collected resource rents (though not too much), but this was a kind of balance of interests at the expense of damaging the natural resource, which is known as "draining the pond to get all the fish". During the period of contracting on the Nanxi River from 1998 to 2004, the mechanism by which the interest in resource land was annihilated by the state-owned situation not only deprived the villagers along the river from getting benefits, but affected their production and their life. In order to maximize the possibility of attracting villagers and organizations along the Yangtze River to collective action groups for resource protection, and to minimize the exclusive cost, Yongjia County has established the principle of "Shared interest replacing collective action". Firstly, the model of state-owned resources being run by folk groups is used to resolve the contradiction between the long-standing view of state-owned resources and the free resource views of villagers along the Nanxi River. The villagers along the Nanxi River gave up the unspoken rule of "to make a living, only to local advantage", recognizing the provisions of national laws on the ownership of fishery resource in the Nanxi River, and the state-owned resource representatives only undertake the responsibilities of planning and supervising the resource, and do not specifically participate in resource management. Secondly, the rights of managing resources were given to the lower level, absorbing the organizations of towns 
and villages along the Nanxi River as the main body of resource management. Thirdly, the practice of collecting resource fees by the county agricultural bureau alone was changed into proportional distribution, mainly distributing to the rural management organizations. It is precisely under the resolution, attraction and arrangement of this mutual benefit mechanism that the originally regulated party has been changed into the "Civilian Guardian Team", and the rural organizations and the related administrative departments that were originally "marginalized" are now the empowered, responsible and beneficial main management bodies.

\subsection{Establishing the Common-Running Community for Familiar Resources and Reducing the Discount Rate of Resource}

Establishing the principle of "interest-sharing" can motivate all the parties to participate in the protection of the river, but to convert this enthusiasm into effectiveness, it is also necessary to select the appropriate resource management mechanism according to the characteristics of the fishery resource in the Nanxi River and to local conditions. Based on summarizing the lessons of the previous two failures of contracting, the Yongjia County government re-integrated the fishery resources in the Nanxi River into several "closed" public resources by means of subcontract. At the same time, in order to avoid sub-contract after repeated subcontract, (like arbitrarily dividing the flesh of a Tang Dynasty monk), or a bonus or benefit that is pursued at any cost, the construction of the mechanism of "returning to zero" was strengthened. This includes three aspects: first, the whole river basin abides by a unified time of fishing, avoiding the subcontractors cutting the river basin and draining ponds to catch all the fish; second, the subcontractors are the villagers living near the waters. The length of each contracting section is generally less than $10 \mathrm{~km}$, which is conducive to familiarity with the characteristics of the resource and the environment of the contracted area, deepening feelings for the contracted resources, and also ensuring familiarity between the adjacent contractors, so as to exchange information and supervise each other; third, the authorized organizations of towns and villages in the resource areas supervise the business operations of the contractors in the region and the fishing activities of others. So the regulators are familiar with the river surface and the supervised persons, which is conducive to the supervisory party's grasp of information on violations. The implementation of the above-mentioned mechanism has promoted the formation of a familiar business contracting area among the regulators, the upstream contractors, the downstream contractors, the villagers along the river and the fishery resources. In such a business environment, there is no need to worry about the other side, for example, between the regulators and the regulatory targets, between the contractors, or between the contractors and other villagers, so the cost of supervision is naturally reduced. At the same time, the contractor can rest the river to save fish and the contract discount rate is greatly reduced.

\subsection{Based on the Collegiate 'from up to down', Institutional Arrangements Are Closer to the Truth}

In order to prevent the parties from worrying about the current contracting mechanism and the carrying out of the river protection plan, the Yongjia County government has made four reforms, coinciding with the interest of people in opening the rules to all parties concerned. First, in the determination of the system of fishing, the opinions of experts and villagers along the river were extensively sought, and an informants' hot-line telephone was set up to let the public know and to accept the supervision of the whole people. Second, the towns along the Nanxi River were given the right to issue rights. The specific contract and contract methods are formulated by the towns. Third, the villagers' committee along the Nanxi River was authorized to organize the villagers to make the rules for the protection of fishing, and to recognize the rules' effective management without violating national laws. Fourth, establishing a network platform such as the fishery in the Nanxi River, the government network and the tourism network, disclosing the contents of various management systems and rules, and encouraging all parties to express their views on protecting the river. These practices have successfully linked national laws, local policies, village regulations and public opinions, and ensured that all parties involved in the fishery resources of the Nanxi River have the right to know and speak about the institutional arrangements for resource management. 
Under such a mechanism, the institutional arrangements can better express the will of the parties and reflect local facts, which can not only ensure the validity of the rules, but also strengthen the obligations of the parties to abide by the rules.

\subsection{Strictly Control the "Free Rider" to Ensure the Normalization of the Collective Protection of the River}

Ostrom has summed up the three situations in which "free-riding" behavior harms the collective interest: if a person can share the achievements made by others through "free-riding", the person will not have the motivation to make a contribution to the common interests; some provide collective goods while others are "free riders", which will not lead to the optimal supply of "collective interests"; if all the people choose to be a "free rider", collective benefits are not achieved." These three situations can be boiled down to the fact that it is actually a truth that if there is "free rider" behavior that is not regulated, the collective interest cannot be effectively supplied. The reason why the previous two contracts failed to control the "free rider" can provide three important lessons: first, the supervision system could not be separated; second, the supervision responsibility should be clear; third, the supervision power should be dispersed. The new contract model transforms these three lessons into corresponding regulatory mechanisms. First, the county government set up the leading group, the Nanxi River Fishery Resources Protection Leading Group, which is headed by the county magistrate with members of the departments of agriculture, public security, tourism, commerce, environmental protection, water conservancy and finance, and established a unified supervision and management system for planning uniformly the protection work of fishery resources in the Nanxi River, and determining the management process of rules and coordination. Second, under the premise that the government's competent functional departments shoulder the responsibility of protecting the river, all relevant parties share the corresponding specific responsibilities. The daily protection of fisheries is the responsibility of the contractor; the town government and the village carry out publicity and education among the masses, formulate the fishing regulations, mediate fishery disputes, and assist the county's law enforcement departments in handling violations; the law enforcement department promptly handles cases of violation of laws and regulations and protects the legitimate rights and interests of contractors; the public security department cooperates in a timely manner to improve the efficiency of fishery law enforcement, deal with illegal cases, and crack down on illegal, criminal acts such as "electrocuting, poisoning, and bombing fish". Third is adopting the measure of grading sanctions and blocking all possible ways to breed "free rider" behavior. The implementation of this series of mechanisms has constituted a strong psychological pressure and cost pressure on the people who demonstrated "free-riding" behavior. As long as we replay the scene of "when finding someone is poisoning the fish, neighbors will come to tell the contractors", one can imagine how powerful the resulting network of regulated "free-riding" behavior [31].

\section{Conclusions and the Direction of Policy Improvement}

The case of the management contract of fishery resources in the Nanxi River progressing from failure to success vividly demonstrates the logic of how to form collective action in the process of protecting a state-owned open public resource, which can reveal some common issues:

(1) Collective action is the basic premise for the protection of public resources. However, the large-scale characteristics of state-owned open public resources and the complex environments they face will create a huge "bottleneck" against the formation of collective protection actions. For example, there are some difficulties in forming consensus and in supervising, large differences in the interests of all parties, high exclusion costs, and high resource discount rates. There is a near-paradoxical relationship between the two, which also determines that the protection of state-owned open public resources is more challenging than the protection of closed public resources belonging to a certain village or small-scale collective and requires a more scientific approach.

(2) To transform the paradoxical relationship between state-owned open public resources and collective protection actions into mutually supportive relationships, it is necessary to establish a system 
of mechanisms that promote collective action. In general, this should include five organic parts, namely consensus, sharing, cooperation, discussion, and co-management, so that they are able to break the aforementioned "bottleneck".

(3) In the process of the operation and protection of state-owned open public resources, it is necessary to avoid simply depriving the rights of other resource-related parties, especially the rights and interests of organizations and citizens in the resource-owned areas by simply annihilating the latent rules of history with a formal system. Efforts should be made to balance the interests of all parties, assimilate the various codes of conduct, minimize conflicts, and improve the environment for the operation and protection of state-owned open public resources.

(4) When introducing the contracting system into the operation and protection of state-owned open public resources, a competent department of state-owned resources must adhere to the functions and responsibilities of management, and avoid cutting-edge contract or monopoly contract putting business philosophy and economic benefits first, which means that the responsibility for rights and resource protection is contracted without any limitations.

Certainly, the collective protection action mechanism of fishery resources in the Nanxi River also has its particularity and needs to be further improved: firstly, the contracting cycle is short; secondly, the mechanism for resource stakeholders to participate in making the rules is not enough. Both of these points are related to the sustainability of fisheries resource conservation actions, or to the issue of "reassuring". It is well known that when an action mechanism is proven to be effective and reasonable, its overall effectiveness is proportional to its duration. The management contract of fishery resources in the Nanxi River has only one cycle of three years, which is shorter than the normal growth cycle of many rare fish species, and this makes it impossible for contractors to further reduce the resource discount rate. In addition, in the current rule-making mechanism for the collective protection of fishery resources in the, Nanxi River, only the issues of the right to know and the right to speak of all parties involved in the resource have been resolved without absorbing the mechanism for all parties, especially the villagers and contractors along the river. to participate in the voting. According to Ostrom's investigation of 14 global public resource management cases, collective selection forums were set up in all six successful cases as a mechanism for parties to participate in the rules of the game. Of the other eight unsuccessful cases, only two implemented the mechanism [32]. This shows that the collective choice forum mechanism is an important variable that contributes to collective action. The collective protection action mechanism of the fishery resources in the Nanxi River also needs to make further achievements in this regard.

Author Contributions: Formal analysis, J.G.; Funding acquisition, S.L.; Investigation, J.L. and S.L.; Resources, J.L.; Supervision, J.G.; Validation, F.T.-H.; Writing—original draft, J.G. and J.L.; Writing-review \& editing, S.L. and F.T.-H. All authors have read and agreed to the published version of the manuscript.

Funding: This research was funded by The New Type Key Think Tank of Zhejiang Province "China Research Institute of Regulation and Public Policy",Zhejiang province Funds for Distinguished Young Scientists (Grant No.: LR15E090002) and the National Natural Science Foundation of China (Grant No: 51379219, 41371187).

Conflicts of Interest: The authors declare no conflict of interest.

\section{References}

1. Moseley, A.; Stoker, G. Nudging citizens? Prospects and pitfalls confronting a new heuristic. Resour. Conserv. Recycl. 2013, 79, 4-10. [CrossRef]

2. Soomro, A.B.; Salleh, N.; Mendes, E.; Grundy, J.; Nordin, A. The effect of software engineers' personality traits on team climate and performance: A Systematic Literature Review. Inf. Softw. Technol. 2016, 73, 52-65. [CrossRef]

3. Bentley, A.F. The Process of Government; The University of Chicago Process: Chicago, IL, USA, 1908.

4. Willoughby, C. How much can public private partnership really do for urban transport in developing countries? Res. Transp. Econ. 2013, 40,34-55. [CrossRef] 
5. Ciriacy-Wantrup, V.S.; Bishop, R.C. "Common Property" as a Concept in National Resource Policy. Nat. Resour. J. 1975, 15, 713-727.

6. Emerson, D.; Mulley, C.; Bliemer, M.C.J. A theoretical analysis of business models for urban public transport systems, with comparative reference to a Community Franchise involving Individual Line Ownership. Res. Transp. Econ. 2016, 59, 368-378. [CrossRef]

7. Jamison, D.T.; Summers, L.H.; Alleyne, G.; Arrow, K.J.; Yamey, G. Global health 2035: A world converging within a generation. Lancet 2013, 382, 1898-1955. [CrossRef]

8. Angwin, D.N.; Meadows, M. The Choice of Insider or Outsider Top Executives in Acquired Companies. Long Range Plan. 2009, 42, 359-389. [CrossRef]

9. Ostrom, E. Governing the Commons: The Evolution of Institutions for Collective Action; Cambridge University: Cambridge, UK, 1990.

10. Lu, S.B.; Zhang, X. Evolutionary Analysis on Structural Characteristics of Water Resource System in Basins of Northern China. Sustain. Dev. 2020, 1-13. [CrossRef]

11. Úbeda, J.A.P.; de Burgos Jiménez, J.; Ureña, L.J.B. Stakeholders, environmental management and performance: An integrated approach. Cuad. Econ. Dir. Empresa 2011, 14, 151-161. [CrossRef]

12. Petrosillo, I.; Aretano, R.; Zurlini, G. Socioecological Systems. Encycl. Ecol. (Second Ed.) 2015, 4, 419-425.

13. Mikalsen, K.H.; Jentoft, S. From user-groups to stakeholders? The public interest in fisheries management. Mar. Policy 2001, 25, 281-292. [CrossRef]

14. Allwood, J.M.; Ashby, M.F.; Gutowski, T.G.; Worrell, E. Material efficiency: A white paper. Resour. Conserv. Recycl. 2011, 55, 362-381. [CrossRef]

15. di Gregorio, L.T.; Soares, C.A.P. Post-disaster housing recovery guidelines for development countries based on experiences in the American continent. Int. J. Disaster Risk Reduct. 2017, 24, 340-347. [CrossRef]

16. Pauly, D. Beyond duplicity and ignorance in global fisheries. Sci. Mar. 2009, 73, 215-224. [CrossRef]

17. Mitrea, M.; Monniaux, S. The regularity of the Stokes operator and the Fujita-Kato approach to the Navier-Stokes initial value problem in Lipschitz domains. J. Funct. Anal. 2008, 254, 1522-1574. [CrossRef]

18. Carreon, M.E.; Moghadam, V.M. "Resistance is fertile": Revisiting maternalist frames across cases of women's mobilization. Women's Stud. Int. Forum 2015, 51, 19-30. [CrossRef]

19. Purtova, N. Property rights in personal data: Learning from the American discourse. Comput. Law Secur. Rev. 2009, 25, 507-521. [CrossRef]

20. Parcu, P.L.; Silvestri, V. Electronic communications regulation in Europe: An overview of past and future problems. Util. Policy 2014, 31, 246-255. [CrossRef]

21. Aznar-Sánchez, J.A.; Belmonte-Ureña, L.J.; Velasco-Muñoz, J.F.; Manzano-Agugliaro, F. Economic analysis of sustainable water use: A review of worldwide research. J. Clean. Prod. 2018, 198, 1120-1132. [CrossRef]

22. Ramírez, R.; Selsky, J.W. Strategic Planning in Turbulent Environments: A Social Ecology Approach to Scenarios. Long Range Plan. 2016, 49, 90-102. [CrossRef]

23. Lu, S.; Bai, X.; Li, W.; Wang, N. Impacts of climate change on water resources and grain production. Technol. Forecast. Soc. Chang. 2019, 143, 76-84. [CrossRef]

24. le Heron, R.; Lewis, N.; Fisher, K.; Thrush, S.; Ellis, J. Non-sectarian scenario experiments in socio-ecological knowledge building for multi-use marine environments: Insights from New Zealand's Marine Futures project. Mar. Policy 2016, 67, 10-21. [CrossRef]

25. Huck, S.; Lünser, G.; Spitzer, F.; Tyran, J.-R. Medical insurance and free choice of physician shape patient overtreatment: A laboratory experiment. J. Econ. Behav. Organ. 2016, 131, 78-105. [CrossRef]

26. Olson, M. The Logic of Collective Action: Public Goods and the Theory of Groups; Harvard University Press Cambridge: London, UK, 1965; pp. 159-192.

27. Lu, S.B.; Zhang, X.L.; Bao, H.J.; Skitmore, M. Review of social water cycle research in a changing environment. Renew. Sustain. Energy Rev. 2016, 63, 132-140. [CrossRef]

28. Truman, D.B. The Governmental Process. New York: Knopf. Robert P W. The Governmental Process: Political Interests and Public Opinion, New York: Alfred A. Knopf. Chapter. Am. J. Agric. Econ. 1952, $34,741$.

29. Samusikov, V.P. Regularities in the impurity element content of minerals during hydrothermal ore formation. Russ. Geol. Geophys. 2010, 51, 266-276. [CrossRef] 
30. Springer, V.A.; Lalasz, C.B.; Lykes, V.A. Social action in response to terrorism: Understanding xenophobic violence from a value-added perspective. Soc. Sci. J. 2012, 49, 175-182. [CrossRef]

31. Saini, V.; Garcia-Armesto, S.; Klemperer, D.; Paris, V.; Fisher, E.S. Drivers of poor medical care. Lancet 2017, 390, 178-190. [CrossRef]

32. Wu, Y.; Chen, L.; Cheng, C.; Yin, K.; Török, Á. GIS-based landslide hazard predicting system and its real-time test during a typhoon, Zhejiang Province, Southeast China. Eng. Geol. 2014, 175, 9-21. [CrossRef]

(c)

(C) 2020 by the authors. Licensee MDPI, Basel, Switzerland. This article is an open access article distributed under the terms and conditions of the Creative Commons Attribution (CC BY) license (http://creativecommons.org/licenses/by/4.0/). 